\title{
Ultrasonographic determination of goiter prevalence in southern Brazilian schoolchildren
}

H.R.K. Lisbôa ${ }^{1}$ and J.L. Gross ${ }^{2}$

\author{
Correspondence \\ J.L. Gross \\ Serviço de Endocrinologia \\ Hospital de Clínicas de Porto Alegre \\ Rua Ramiro Barcelos, 2350 \\ Prédio $12,4^{\circ}$ andar \\ 900035-003 Porto Alegre, RS \\ Brasil \\ Fax: + 55-51-330-9100/332-5188 \\ E-mail: gross@ hotnet.net \\ Research partially supported by \\ CNPq and Hospital de Clínicas de \\ Porto Alegre. H.R.K. Lisbôa was \\ the recipient of a scholarship \\ from CAPES.
}

Received May 16, 2001

Accepted July 10, 2002

\author{
${ }^{1}$ Departamento de Medicina, Faculdade de Medicina, \\ Universidade de Passo Fundo, Passo Fundo, RS, Brasil \\ 2Divisão de Endocrinologia, Hospital de Clínicas de Porto Alegre, \\ Universidade Federal do Rio Grande do Sul, Porto Alegre, RS, Brasil
}

\section{Abstract}

The aim of the present study was to estimate the prevalence of goiter in schoolchildren in a formerly iodine-deficient region in southern Brazil by assessing the relationship between body surface area $\left(\mathrm{m}^{2}\right)$ and thyroid volume $(\mathrm{ml})$ measured by ultrasonography. A populationbased sample of 1,094 randomly selected schoolchildren (6 to 14 years; 556 boys and 538 girls) underwent clinical evaluation. A total of $119(10.9 \%)$ children were diagnosed with goiter upon clinical examination according to WHO criteria (grade Ia: 65, grade Ib: 24, grade II: 29, grade III: 1). Of these, 85 underwent ultrasonography. In order to ascertain the absence of goiter in the 975 schoolchildren with a negative result upon clinical examination, one of ten children was randomly selected for ultrasonography. Sixty-two children agreed to be submitted to the exam. Thus, 147 schoolchildren were evaluated by ultrasonography (7.5-MHz transducer). Goiter was considered to be present when the thyroid volume:body surface area index was $>6.2 \mathrm{ml} /$ $\mathrm{m}^{2}$. The estimated prevalence of goiter if all schoolchildren had been submitted to thyroid volume measurement by ultrasound was $7.2 \%$; it was higher in the lower socioeconomic class $(8.2 \%)$ than in the upper $(7.8 \%)$ and middle classes $(6.5 \%)$. In conclusion, the prevalence of goiter in schoolchildren of this region was higher than in other iodinesufficient areas, especially in lower socioeconomic classes. Goiter in this region may be associated with naturally occurring goitrogens that operate more intensively among less privileged individuals.

\section{Key words}

- Goiter

- Prevalence

- Thyroid gland

- Ultrasonography

\section{Introduction}

The diagnosis of goiter has been traditionally based on inspection and palpation of the thyroid. According to the World Health Organization (WHO) (1), the presence of goiter is established when the thyroid lobes are larger than the terminal phalanges of the thumb of the person being examined. However, the clinical examination of thyroid volume often overestimates the presence of goi- ter, especially in children (2). Ultrasonography is a more precise method to determine thyroid volume (2) and has been recommended as the standard criterion in epidemiological surveys (3). However, the cost of this procedure may sometimes prevent its use.

We have previously shown that thyroid volume measured by ultrasonography presents a strong correlation with body surface area in schoolchildren, and that the index derived from this correlation (Echobody in- 
dex) is a reliable measure for establishing a normal reference range for thyroid volume (4). Others have also observed an association between thyroid volume and body surface area in both children (5) and adults (6), and the variation of body surface area has been considered to be the main determinant of thyroid volume (7).

In addition to body surface area, several other factors are associated with thyroid volume, the best known being iodine deficiency. The recommended intake of iodine is $150 \mu \mathrm{g} /$ day for adults. This corresponds to a urinary concentration of approximately 10 $\mu \mathrm{g} / \mathrm{dl}(8)$. Before the salt iodination program was fully implemented in Brazil in 1983 (9), the highland region of the State of Rio Grande do Sul was considered to be iodine deficient. A study performed in 1955 (10) showed that $31.4 \%$ of young adults from the region of Passo Fundo were not accepted for military compulsory service due to the presence of goiter.

Therefore, the objective of the present study was to estimate the prevalence of goiter by ultrasonography in this city located on the highlands of southern Brazil. Thyroid volume was determined by the Echobody index as previously reported (4).

\section{Patients and Methods}

The study was carried out in 1994 in the city of Passo Fundo, located in the highland region ( $800 \mathrm{~m}$ altitude) of southern Brazil. In 1998, the average urinary iodine excretion (Sandell-Kolthoff method) detected in random urinary samples of 100 schoolchildren was $22 \mu \mathrm{g} / \mathrm{dl}(11)$.

A total of 1,127 schoolchildren aged 6 to 14 years were selected randomly among the entire population of 21,544 schoolchildren. The sample size calculation for a confidence level of $95 \%$ and assuming a proportion of 5 and $15 \%$ of schoolchildren with goiter indicates that 377 students should be representative of the population. The sample was se- lected on the basis of data from the City Department of Education, which provided a list of the 66 public and private schools and of the schoolchildren enrolled in them. According to the Brazilian Geography and Statistics Institute, the population living in the city was 165,000 inhabitants. The distribution of the schools according to socioeconomic status was: 39 lower-class schools, 16 middle-class schools, and 11 upper-class schools. Seven of these schools were studied (three lower-class, two middle-class, and two upper-class ones).

Schools, shifts, and students in each classroom were all chosen randomly by drawing lots. In the classroom, each student was assigned a number (starting with 1). Then, the teacher was asked to select a number from 1 to 10 . The students who had been assigned numbers that were multiples of that selected by the teacher took part in the study. Twentyone children with a history of thyroid disease and 12 who had used drugs containing iodine (potassium iodine syrup or topical solutions) during the three months before the study were excluded. Therefore, 1,094 schoolchildren ( 556 boys and 538 girls) underwent clinical examination to detect the presence of goiter.

For each subject, an identification form was completed and the following data were obtained: name of the school, grade, name of the student, place of birth, age, and sex. Weight, height, and triceps skinfold thickness (measured with a Harpenden caliper at the midpoint between olecranon and acromion) were determined. Body surface area was obtained using a normogram based on weight and height. A total of 147 individuals agreed to undergo ultrasonography. Informed consent was obtained from the children's parents or legal representatives. The study was approved by the Ethics Committee of Hospital de Clínicas de Porto Alegre.

Goiter was defined by clinical examination according to WHO criteria (1) as follows: grade 0 , absence of palpable thyroid 
tissue; grade Ia, palpable thyroid with lateral lobes larger than the distal phalanx of the thumb of the child who was being examined; grade $\mathrm{Ib}$, thyroid visible when the subject swallows with head extended; grade II, thyroid visible with head in normal position; grade III, thyroid bulky and visible at a distance. The child was asked to swallow with the head in normal position, with the doctor standing in front of him/her. Then, with the head extended, the gland was inspected and the thyroid was palpated with the thumbs while the child was asked to swallow again. All children were examined by one of the authors (H.R.K. Lisbôa).

Ultrasonography was performed using an Aloka 630 instrument with a $7.5-\mathrm{MHz}$ transducer, always by the same physician, who was not aware of the results of clinical examination. The volume of each lobe was calculated according to the formula anteroposterior $\mathrm{x}$ transversal $\mathrm{x}$ longitudinal diameters $\mathrm{x} 0.52$. The results for each lobe were summed to obtain the total volume. The mean coefficient of variation of two measurements separated by a 15-day interval in eight young adults was $3.9 \%$.

The ratio of thyroid volume to body surface area (Echobody index) was considered as the standard criterion to define thyroid size in this sample of schoolchildren. Thus, all children with an Echobody index equal to or higher than $6.2 \mathrm{ml} / \mathrm{m}^{2}$ (upper limit of normality) were considered to have an increased thyroid volume. This value was calculated on the basis of the 95th percentile of the distribution curve for 62 children without goiter upon clinical examination that underwent ultrasonography in the present study.

The prevalence of goiter in the population was estimated by calculating the number of schoolchildren that would probably have goiter if all the population had undergone ultrasound examination of the thyroid. The distribution of schoolchildren with goiter in each socioeconomic class was calculated with a formula (12) that employs posi- tive and negative predictive Echobody index values: actual prevalence $=\{$ (positive test $\mathrm{x}$ positive predictive value $)+$ [negative test $x$ (1-negative predictive test value)]\}. We have previously demonstrated that clinical examination has a sensitivity of $41 \%$ for diagnosing goiter, a specificity of $91 \%$, a positive predictive value of $27 \%$ and a negative predictive value of $95 \%$ (4).

\section{Statistical analysis}

Data are reported as means $\pm \mathrm{SD}$. The adopted level of significance was $5 \%$. The unpaired Student $t$-test was used for comparison between means and the chi-square test was used to compare proportions.

\section{Results}

One hundred and nineteen (10.9\%) of the 1,094 schoolchildren examined were considered to have goiter upon clinical examination. The distribution of goiter size according to WHO criteria is shown in Table 1. Most goiters were classified as grade Ia. Eighty-five children in this group agreed to undergo ultrasonography. Sixty-two children with a negative clinical examination agreed to be submitted to the exam. Therefore, 147 schoolchildren (85 with goiter and 62 without goiter upon clinical examination) were evaluated by ultrasonography.

According to the Echobody index, three schoolchildren (4.8\%) with goiter were iden-

Table 1. Distribution of goiter size according to WHO criteria in 119 schoolchildren.

\begin{tabular}{lc}
\hline Goiter size & $\begin{array}{c}\text { Number and percentage } \\
\text { of schoolchildren }\end{array}$ \\
\hline la & $65(55 \%)$ \\
Ib & $24(20 \%)$ \\
II & $29(24 \%)$ \\
III & $1(1 \%)$
\end{tabular}

The classification system for goiter size is given in the Methods section. 
tified among the 62 thought not to have goiter upon clinical examination, and 23 $(27.05 \%)$ in the group of 85 individuals with goiter upon clinical examination. The group with goiter according to the Echobody index $(\mathrm{N}=26)$ did not differ from the group without goiter $(\mathrm{N}=121)$ regarding age, distribution of sex, body surface area, or skinfold thickness. The number of lower-class children with goiter was significantly higher (chi-square $=6.24, \mathrm{P}=0.04)$ (Table 2).

Based on these data, if all the 1,094 schoolchildren had been submitted to ultrasonography, it would be possible to estimate that 47 children ( $4.8 \%$ of 975$)$ would have been diagnosed as having goiter according to the Echobody index in the group thought not to have goiter on the basis of clinical examination, and $32(27.05 \%$ of 119$)$ in the group found to have goiter upon clinical examination. According to this inference, 79 individuals would have goiter on ultrasound assessment. Extrapolating these findings to all schoolchildren $(1,094 / 79)$, we estimate that $7.2 \%$ probably had an enlarged thyroid.

When the students were classified according to socioeconomic status, the estimated prevalence of goiter was $8.2,7.8$, and $6.5 \%$ in the lower, middle and upper classes, respectively. This estimate was obtained using the prevalence found in the sample extrapolated to the 1,094 school children.

Table 2. Clinical characteristics of schoolchildren with and without goiter according to the Echobody index.

\begin{tabular}{lcc}
\hline & Without goiter & With goiter \\
\hline Gender (male/female) & $64 / 57$ & $14 / 12$ \\
Age (years) & $9.8 \pm 1.6$ & $10 \pm 1.7$ \\
Weight $(\mathrm{kg})$ & $31.9 \pm 7.6$ & $31.5 \pm 7$ \\
Height $(\mathrm{cm})$ & $138 \pm 10$ & $139 \pm 9$ \\
Body surface area $\left(\mathrm{m}^{2}\right)$ & $1.12 \pm 0.14$ & $1.21 \pm 0.17$ \\
Skinfold $(\mathrm{mm})$ & $136 \pm 6$ & $119 \pm 5$ \\
Social class $(1 / 2 / 3)$ & $43 / 33 / 45$ & $3 / 8 / 15^{*}$ \\
\hline
\end{tabular}

Data are reported as means \pm SD or number of individuals with the characteristic. Numbers 1, 2 and 3 represent the upper, middle, and lower socioeconomic classes, respectively.

*P $<0.05$ compared to children without goiter (chi-square test).

\section{Discussion}

The estimated goiter prevalence of $7.2 \%$ in the schoolchildren of Passo Fundo, Brazil, is higher than the $5 \%$ value detected in regions where urinary iodine is above $10 \mu \mathrm{g} / \mathrm{dl}$ (8). Epidemiological studies measuring thyroid volume by ultrasonography and taking into account height, body weight and age have reported a goiter prevalence of $3.9 \%$ in iodine-sufficient areas (13). In iodine-deficient areas in Italy (13) and around Chernobyl in the former Soviet Union (14), the reported prevalence of goiter was 25.3 and $35.9 \%$, respectively.

Current iodine deficiency alone does not explain the increased prevalence of goiter detected in this study. Since the salt iodination program in Brazil was implemented in 1983 (9), the average urinary iodine excretion in this region has reached $22 \mu \mathrm{g} / \mathrm{dl}$, above the value of $10 \mu \mathrm{g} / \mathrm{dl}$ established as the minimum for iodine sufficiency (8). In addition, the normal reference range for thyroid volume in the region $\left(6.2 \mathrm{ml} / \mathrm{m}^{2}\right)$ is very similar to that reported for iodine-sufficient regions using ultrasonography and taking into account body surface area (5). Even considering that in order to reduce thyroid weight in endemic areas it is necessary to have an adequate supply of iodine for at least 25 years (15), other factors may be associated with the increased occurrence of goiter in Passo Fundo (16).

Several goiter endemias have been associated with exposure to naturally occurring goitrogenic and antithyroid agents in foodstuffs and drinking water (17). These goitrogenic agents act directly on the thyroid gland, interfering with the main steps of thyroid hormone production or altering the excretion of thyroid hormones. Several foodstuffs have been implicated in goiter endemias (such as cassava, millet, babassu, seaweeds, piñon nut) due to the presence of compounds with antithyroid action, e.g., thiocyanate, thiooxazolidone, and flavonoids. Soybean has 
also been implicated in the development of goiter, probably due to the inhibition of thyroid peroxidase by the isoflavones genistein and daidzein (18). It is interesting to note that Passo Fundo is located within a soybean growing area and, although the intake of soybean products was not evaluated, it could be higher there than in other areas.

Increased prevalence of goiter has also been related to undernutrition and bacterial pollution of drinking water (19). The presence of Escherichia coli may decrease iodine uptake; furthermore, there is evidence of mimicry of antigens from this bacterium and human thyroid plasma membrane which can trigger an autoimmune reaction (16). Recently it was reported that the molecular mimicry of thyroid antigens by bacteria was a local sequence homology between sodium/ iodide symporters and a number of both bacterial and viral proteins. The authors suggested that cross-reactivity with sodium/iodide symporters by antibodies originally against microorganisms may compromise iodide uptake by the thyroid, thus increasing the prevalence of goiter in a polluted environment (20). Probably, water pollution was also a relevant factor in our study, especially for the lower social class, in which the prevalence of goiter was higher than in the middle and upper classes.

Goiter in these schoolchildren also could have been due to chronic autoimmune thyroiditis. However, although antithyroid antibodies were not measured, this is an unlikely explanation for the presence of goiter in this study, since in only one patient did we observe a thyroid with an irregular surface and firm consistency, characteristic of Hashimoto's thyroiditis. Furthermore, the prevalence of autoimmune thyroiditis in adolescents is only $0.35 \%(21)$.

This study has two potential limitations. The interval between thyroid examination and the measurement of urinary iodine in the population was of approximately 4 years. However, this probably did not constitute a major caveat because a sufficient iodine supply for the Brazilian population has been assured since 1983 (22).

Secondly, the definition of goiter used was based on the 95th percentile of the distribution curve for 62 children without goiter upon clinical examination. However, according to recommendations of the $\mathrm{WHO}(8)$, the cutoff value should be $97 \%$ for a population of children with normal iodine intake. When the $97 \%$ cutoff of the distribution of children without goiter is used we obtain $7.2 \mathrm{ml} / \mathrm{m}^{2}$ as the upper limit of the reference range for our study group. Using this value rather than the 95th percentile cutoff value $\left(6.2 \mathrm{ml} / \mathrm{m}^{2}\right)$ which was used in the present study, we obtain $4 \%$ of children with goiter for the entire population (extrapolated to 1,094 children) and 4.2, 3.5 , and $4 \%$ for children of lower, middle and upper socioeconomic classes, respectively (extrapolated to 404, 506 and 186 children of the above socioeconomic classes) based on the Echobody index. As expected, using the higher cutoff value decreased the percentage of schoolchildren having goiter. However, the WHO recommendation was based on a European study which was recognized to have a systematic measurement bias resulting in an overestimation of the thyroid volume (23). Furthermore, the $95 \%$ cutoff value adopted in our study $\left(6.2 \mathrm{ml} / \mathrm{m}^{2}\right)$ agrees better with other accepted standards $(6.5 \mathrm{ml} /$ $\mathrm{m}^{2}$ ) than the $97 \%$ cutoff value of $7.2 \mathrm{ml} / \mathrm{m}^{2}$ $(5,23)$.

The increased prevalence of goiter diagnosed by ultrasonography in the schoolchildren of this currently iodine-sufficient region may be related to the presence of naturally occurring goitrogens operating more intensively among less privileged individuals.

\section{Acknowledgments}

The authors thank Dr. Ademir Orsolin, Clínica de Ecografia, Passo Fundo, RS, Brazil, for performing the ultrasonography. 


\section{References}

1. Delange $F$, Bastiani $S$, Benmiloud $M$, DeMayer E, Isayama MG, Koutras $D$, Muzzo S, Niepomniszcze H, Pandav CS \& Riccabona G (1986). Definitions of endemic goiter and cretinism, classification of goiter size and the severity of endemias, and survey techniques. In: Dunn JT, Pretell EA, Daza CH \& Viteri SE (Editors), Towards the Eradication of Endemic Goiter, Cretinism, and lodine Deficiency. Pan American Health Organization, Scientific Publication No. 502, Washington, DC, USA, 373.

2. Rasmussen $S N \&$ Hjorth $L$ (1974). Determination of thyroid volume by ultrasonic scanning. J ournal of Clinical Ultrasound, 2: 143-146.

3. Berghout A, Wiersinga WM, Smits NJ \& Touber J L (1987). Determinants of thyroid volume as measured by ultrasonography in healthy adults in a non-iodine deficient area. Clinical Endocrinology, 26: 273280.

4. Lisbôa HRK, Gross J L, Orsolin A \& Fuchs $S$ (1996). Clinical examination is not an accurate method of defining the presence of goitre in schoolchildren. Clinical Endocrinology, 45: 471-475.

5. Delange $\mathrm{F}$, Benker $\mathrm{G}$, Caron $\mathrm{PH}$, Eber $\mathrm{O}$, Ott W, Peter F, Podoba J, Simescu M, Szybinsky $Z$, Vertongen $F$, Vitti $P$, Wiersinga W \& Zamrazil V (1997). Thyroid volume and urinary iodine in European schoolchildren: standardization of values for assessment of iodine deficiency. European J ournal of Endocrinology, 136: 180-187.

6. Barrère $X$, Valeix $P$, Preziosi $P$, Bensimon $M$, Pelletier B, Galan $P$ \& Hercberg $S$ (2000). Determinants of thyroid volume in healthy French adults participating in the SU.VI.MAX cohort. Clinical Endocrinology, 52: 273-278

7. Gómez J M, Maravall FJ , Gómez N, Gumà A \& Soler J (2000). Determinants of thyroid volume as measured by ultrasonogra- phy in healthy adults randomly selected. Clinical Endocrinology, 53: 629-634.

8. World Health Organization, United Nations Children's Fund and International Council for Control of Iodine Deficiency Disorders (1994). Indicators for Assessing lodine Deficiency Disorders and their Control through Salt lodination. World Health Organization, Geneva, Switzerland.

9. Medeiros Neto GA (1988). Towards the eradication of iodine deficiency disorders in Brazil through salt iodination programme. Bulletin of the World Health Organization, 66: 637-642.

10. Oliveira PP, Maldonado G, Montedonio J M \& Lacerda EBF (1955). O bócio endêmico no sul do Brasil. Hospital, 47: 91125.

11. Lisbôa HRK (1999). Thyroid volume change during puberty. Doctoral thesis, Universidade Federal do Rio Grande do Sul, Porto Alegre, RS, Brazil.

12. Ahlbon A \& Norell S (1990). Introduction to Modem Epidemiology. Epidemiology Resources Inc., Chestnut Hill, MA, USA, 24.

13. Vitti $P$, Martino N, Lombardi FA, Rago $T$, Antonangeli L, Maccherini $D$, Nanni $P$, Loviseli A, Balestrieri A, Araneo G \& Pinchera A (1994). Thyroid volume measurement by ultrasound in children as a tool for the assessment of mild iodine deficiency. J oumal of Clinical Endocrinology and Metabolism, 79: 600-603.

14. Ashizawa K, Shibata Y, Yamashita S, Namba H, Hoshi M, Yokoyama N, Izumi M \& Nagataki S (1997). Prevalence of goiter and urinary iodine excretion levels in children around Chernobyl. J ournal of Clinical Endocrinology and Metabolism, 82: 3430-3433.

15. Lindberg $O$, Andersson LC \& Lamberg BA (1989). The impact of 25 years of iodine prophylaxis on the adult thyroid weight in Finland. J oumal of Endocrinological Investigation, 12: 789-793.
16. Gaitan E (1990). Goitrogens in food and water. Annual Review of Nutrition, 10: 21-39.

17. Medeiros-Neto G (2001). lodine deficiency disorders. In: DeGrott LL \& J ameson J L (Editors), Endocrinology. Vol. 2. W.B. Saunders Co., Philadelphia, PA, USA, 1529

18. Divi RL, Chang HC \& Doerge DR (1997). Anti-thyroid isoflavones from soybean: isolation, characterization and mechanisms of action. Biochemical Pharmacology, 54: 1087-1096.

19. Gaitan E, Cooksey RC \& Lindsay RH (1986). Factors other than iodine deficiency in endemic goiter: Goitrogens and protein-calorie malnutrition. In: Dunn JT, Pretell EA, Daza CH \& Viteri SE (Editors), Towards the Eradication of Endemic Goiter, Cretinism, and lodine Deficiency. Pan American Health Organization, Scientific Publication No. 502, Washington, DC, USA, 28.

20. Benvenga $S$, Alesci $S$, Trimarchi $F$ \& Facchiano A (1999). Homologies of the thyroid sodium-iodide symporter with bacterial and viral proteins. J oumal of Endocrinological Investigation, 22: 535-540.

21. J aksic J, Dumic M, Filipovic B, Ille J, Cvijetic M \& Gjuric G (1977). Thyroid diseases in a school population with thyromegaly. Archives of Disease in Childhood, 70: 103-106.

22. Pretell EA \& Noguera A (1994). Current status of iodine deficiency disorders in Latin America. Iodine Deficiency Disorders Newsletter, 10: 15-22.

23. Zimmermann $M B$, Molinari L, Spehl $M$, Weidinger-Toth J, Podoba J, Hess S\& Delange F (2001). Updated provisional WHO/ICCIDD reference values for sonographic thyroid volume in iodine-repleted school-age children. Available at: http:// www.people.virginia.edu/\% 7Ejtd/iccidd/ newsletter/feb2001.htm\#c. Accessed February 2001. 